\title{
後頭骨・上位頸椎後方固定術の検討
}

\author{
熊本大学医学部整形外科学教室 \\ 木村千仞・原田正孝 \\ 栄輝已
}

熊本大学医学部脳神経外科学教室

中山俊 郎・福 村 昭 信

\section{Occipito Vertebral Fusion of the Atlanto-Axial Dislocation and Basilar Impression}

By

\section{Kimura, M. Harada \& T. Sakae}

Dept. of Orthop. Surg., Kumamoto Univ. Med. Sch.

\section{T. Nakayama \& A. Fukumura}

Dept. of Neurosurg., Kumamoto Univ. Med. Sch.

Four patients with the congenital atlanto-axial dislocation or basilar impresion were received the decompression and the occipito vertebral fusion. These patients have either or both of the neurological and circulatory disturbance. Two patients were recieved the decompression and the posterior fusion with the bone graft and wiring. Other two patients were received the decompression and the posterior fusion with the bone graft, wiring and acrylic fixation. One of these patients was failed because of the absorption of bone graft and the rupture of wiring, but others showed good fixation.

先天異常その他の原因によって起とってくる環軸椎 変位や Basilar impression では, 時に循環障害や 神経障害がくるととが経験される，ての場合，Skull traction による整復や除圧術により機能的障害因子 を除くとともに，前方または後方からの固定術を必 要とすることが多いが，後頭骨と上位頸椎との固定 (Occipito-Cervical fixation) は必らずしも容易で ない場合がある.最近，われわれは先天異常によると 思われる環軸椎変位 2 例, Basilar impression 2 例 に対して，大後頭孔拡大または， $C_{1}$ Laminectomy などの除圧術に加えて, 骨移植・Wiring·Acrylic fixation などを行い，術式について検討したので報 告する.

\section{症}

例

（症例 1） 27 才, 男, 工員

主訴：両手のシビレ感と四肢の運動障害.

現病症：昭和 45 年突き倒されて 後頭頸部を打った
事がある、昭和 46 年 10 月頃より 誘因なく主訴を覚 え, 手仕事・歩行が困難となり某病院で入院治療を うけたが症状の改善がみられず，昭和 47 年 3 月 本院 内科で Hypophyseal dwarfism と Congenital Atlanto-axial dislocation を指摘され, 当科へ転 科.

現症: 体格小, 栄養不良, 小児様顔貌, 胸腹部臟器 異常なし. 四肢腱反射六進 (十). 上・下肢病的反射 両側共陽性. 脳神経・頸椎部検查その他に異常なし.

Spinal tap は頸椎前屈で Quecken-Stedt 全く上昇 下降なし、レ線上, 環椎前方脱臼し, 前屈位で環軸椎 部脊柱管前後径 $9 \mathrm{~mm}$, 後屈位 $17 \mathrm{~mm}$.

経過：Skull traction 4 週で症状改善なきため, 昭 和 47 年 10 月 Posterior fusion. traction 下に患者 を腹臥位とし, Inion から $\mathrm{C}_{4}$ 迄正中皮切で後頭骨・ $\mathrm{C}_{1} \sim \mathrm{C}_{4}$ 迄の Lamina を出し, 軟部組織を充分除去

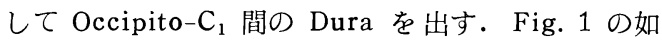
$く, \mathrm{C}_{3}$ 棘突起に Wire をかけ $\mathrm{C}_{2,1}$ Lamina 下涌 
Bone graft + Wiring

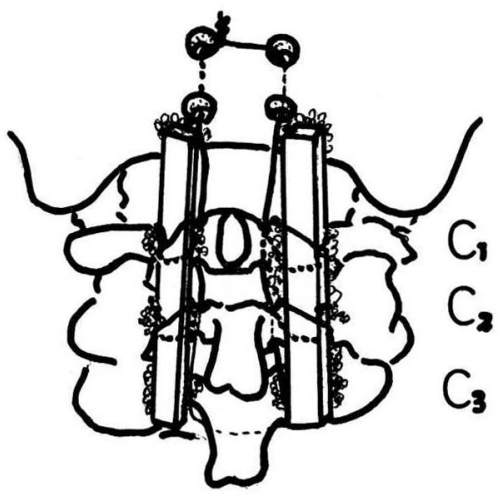

Fig. 1

し, $\mathrm{C}_{1}$ Lamina を後方へ引くようにして後頭骨にあ けた 4 つの孔に通して緊張させて締結. 左右 Lamina と後頭骨に移植骨片を固定. 術後 4 週間 traction 後 Brace をつけ歩行訓練. 腱反射 - 病的反射がやや軽 くなり術後 2 力月で退院. しかし術後 11 力月のレ線 像で後頭部における移植骨吸収とWire の断裂がみ られ, 症状は術前に戻り, 近く再手術の要ある失敗の 1 例である.

（症例 2） 19 才, 女, 無職

主訴 : 四肢の運動障害と頸運動による意識消失. 現 病歴; 昭和 46 年 12 月頃より誘因なく四肢の運動障害 が現われ，某病院で脊喵有腫瘍が疑われ言引をうけたが 症状の改善なく退院. 昭和 48 年 11 月に掃除中, 後を ふり向いたとき眼が暗くなり, 意識を失い転倒して後 頭部挫創, 起坐不能, 排尿困難となり当学脳神経外科 に入院. 諸検査の結果, Basilar impression と診断 されたものである. レ線像では, 環椎後頭骨同化 (Assimilation) が上部頸椎の陥入に合併し, 計測上, Chamberlain, McGregor, Klaus, Orbito-occipital, Bimastoid, Digastria line などに異常を示した。 A-O interval は $6 \mathrm{~mm}$ で亜脱白を示す.

現症：主な所見は, 上下肢筋力低下と筋萎縮, 協調 運動の異常, 痤性歩行, 上下肢腱反射六進と病的反射 陽性. 右上下肢, 左足の知覚鈍麻 $(+)$.

経過：Basilar impression による高位頸蕉道損傷と Vertebral insufficiency と考え, $\mathrm{C}_{1}$ Laminectomy, 大後頭孔拡大に加えて Fig. 2 に示す如き後方固定を 行なった. 即ち後頭骨に 2 つ孔, 移植骨片上端に

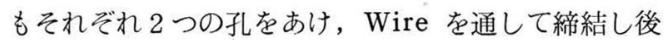

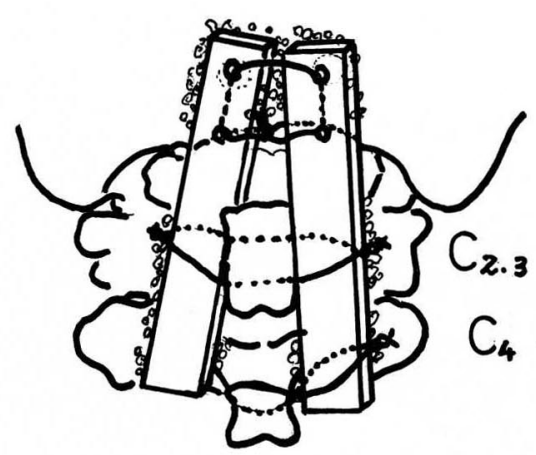

Fig. 2

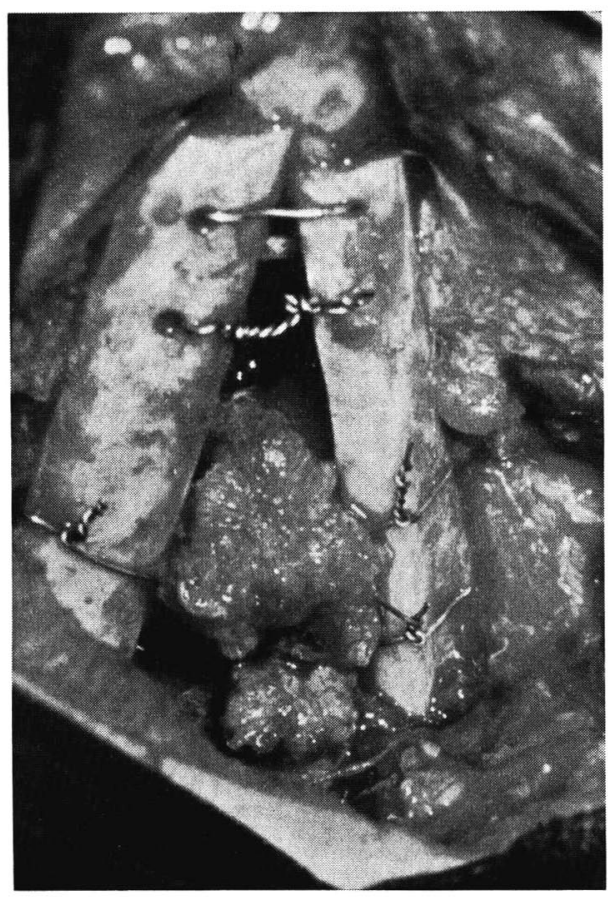

写真 1

頭骨・骨片の固定を強固にした. $\mathrm{C}_{2,3}$ は block を形 成していたので，䊂突起に 2 コの横孔をあけ 2 本の Wire を通して両側の骨片と締結した．固定性は極め て良好であり，周辺に bone chip を詰めて術を終っ た (写真 1 ). 術後 2.5 力月の現在, 右手知覚と右上 下肢の病的反射が改善されているが，慢性腎血腎炎の ためなお入院治療中である. 


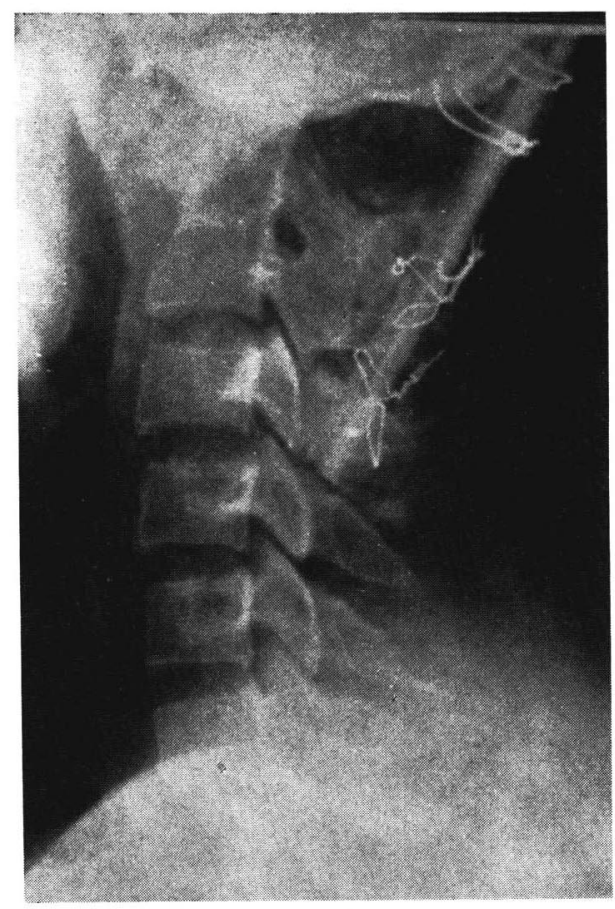

写真 2

（症例 3 ） 30 才, 男, 無職

主訴 : 四肢の運動障害

現病歴 : 幼児期よりつまずき易く，両脚を引きずつ て歩いていた．昭和 45 年 2 月より 両上肢の脱力と共 に臥床を，余儀なくされた， 2,3 の病院で彰療をう

$け$ Morquios disease $\prec$ Atlanto-axial dislocation の診断で同年 7 月当科へ転院.

現症：体格小, 四肢軀幹の筋緊張異常 $(+)$, 病值 性麻痺 (十), 四肢腱反射元進著明, 病的反射 (十). 足部両側知覚鈍麻 (十). Spinal tap 亿著変はない が, Myelography で $\mathrm{C}_{1-2}$ に通過障害あり.レ線像 で歯突起の分離, 前屈でA-O interval $7 \mathrm{~mm}$, 各椎 体は舌状変形,などがみられる.

（症例 4）24才, 男, 国鉄職員

主訴 : 頭痛, 歩行障害, 四肢脱力, 右上方が見えに くい.

現病歴：16才の時, 相撲で頭を強く前屈し, その 後四肢の脱力, 時に頸部以下の電撃痛・頭痛・フラフ ラ感があった．昭和 48 年 3 月頃より, 起床時や頭部 の前屈で頭痛・失神様発作・眼前暗黒感が頻発し, 同 年 12 月とれらの症状が強くなり, 歩行不能となって
当学脳神経外科に入院.

現症：四肢やや病直性で起坐歩行不能. 協調運動右 異常 (十). 両上・下肢腱反射六進し病的反射あり. 右上肢知覚鈍麻, 左上肢知覚過敏あり。レ線計測によ り Basilar impression と Assimilation, Atlantoaxial dislocation が認められ V.A. G. で Basilar artery 移行部, 内後頭動脈の異常久損がある. その 他諸検查所見より vertebral insufficiency, Basilar impression と診断された.

Bone graft + Wiring + Acrylic fixation

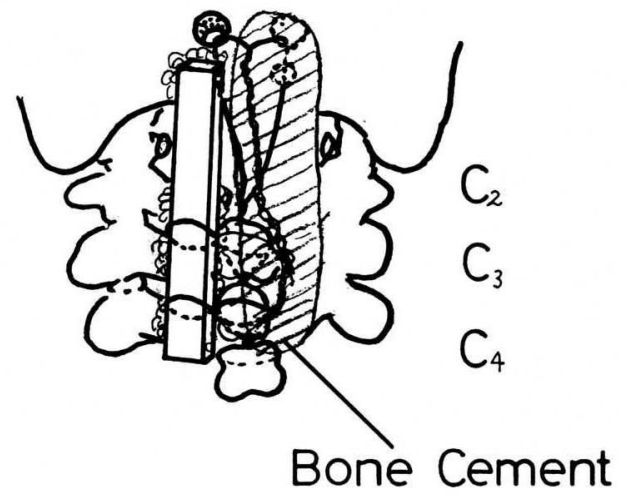

Fig. 3

経過：症例 3 は 11 週間, 症例 4 は術前日より Skull traction を行い Occipito-vertebral fixation を受 けた. 術式の要点は Fig. 3 に示す如く, 頭蓋裏引の まま腹臥位とし，Occipito-Cervical alignment を イメージで確かめたのち, inion から $\mathrm{C}_{5}$ 棘突起まで 綐切す. $\mathrm{C}_{1}$ の Laminectomy, 大後頭孔の拡大によ り除圧したのち, 後頭骨に4 ケの孔をあけ, $\mathrm{C}_{2,3,4}$ 欶 突起に締結した Wire をこの孔に通して結び第1 回 の固定とした．次に移植骨片 $\left(6.5 \times 1 \times 0.5 \mathrm{~cm}^{3}\right)$ の 1 端を後頭骨にあけた孔の1つにつっとみ，他を片側 Lamina そおき $\mathrm{C}_{2,3}$ 欶突起と wire 締結し, 第 2 の 固定とした，次いで反対例で第 1 wire と第 2 の wire を繫ないで，骨セメント内に理没し後頭骨の孔 と䊂突起・decorticate した Lamina そ anchoring して固定した. 固定は強固であった. 術後, 症例 3 は 下肢腱反射は正常となり術後 1 カ月で歩行退院した (写真 3 ).

考按

大孔付近の骨異常および関連奇形に関する報告は欧 
大孔付近の骨異常括よび関連奇形

\begin{tabular}{|c|c|}
\hline $\begin{array}{l}\text { I. 骨異常 } \\
\text { 1) 環椎 · 軸椎 } \\
\text { 1. assimilation of the atlas. } \\
\text { 2. stenosis or deformity of atlas. } \\
\text { 3. atlanto-axial dislocation. } \\
\text { 4. odontoid anomalies, agenesis, os. odon- } \\
\text { toideum ossisculum terminale. } \\
\text { 5. spina bifida. } \\
\text { 6. Klippel-Feil's syndrome. } \\
\text { 7. hemi-or platy-vertedra. } \\
\text { 2) 頭蓋骨 (後頭骨 - 蝶形骨) } \\
\text { 1. platybasia. } \\
\text { 2. basilar impression. } \\
\text { 3. occipital vertebra. } \\
\text { 4. cranium bifidum } \\
\text { 5. stenosis or deformity of foramen mag- } \\
\text { II. num } \\
\text { 1) 管. 䯣膜異常 } \\
\text { 血管奇形 } \\
\text { A. vertebralis, A. cerebelli posterior in- } \\
\text { ferior, A. spinalis posterior-aplasia, hypo- } \\
\text { plasia or dysplasia, corse anomaly. }\end{array}$ & 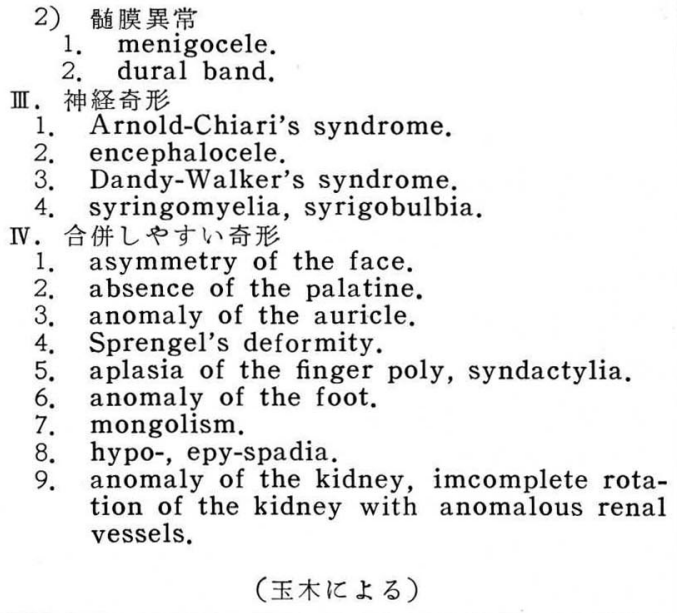 \\
\hline
\end{tabular}

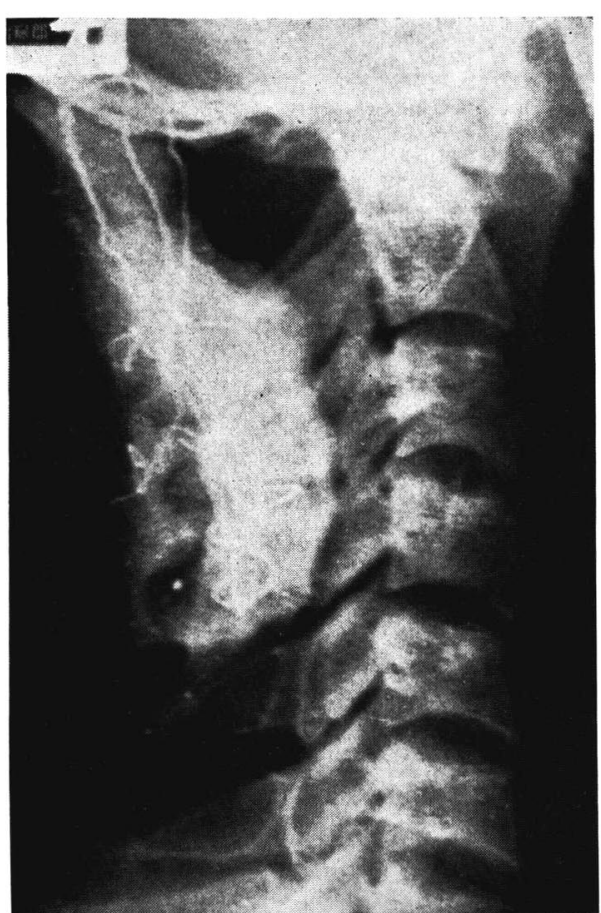

写真 3

米で多数みられ(1)，わが国では佐野2)らをはじめ幾つ かの報告がなされつつある゙ ${ }^{3)}$.

この原因は一次性（先天性）と二次性（後天性）に 分けられ, 通常見られるものは前者である. 分類は表 一にみられる通りである7. 臨床症状の主なものは,
後頸部痛, 㾏性麻痺, めまい, 歩行障害, 頸運動によ る神経症状の増覀, 発語障害・知覚異常などである. 発症の主要因子としては次の 3 つが挙げられる. (1)環 軸椎変位による機械的因子. 諸家の報告ではこの部の 頸盏に萎縮扁平化, Cystic な変性, 般痕化が見られ るという. myelography で完全または部分的狭窄が みられ，われわれの第 3 ・4 例にも同様の所見があっ た. (2)椎骨動脈循環障害. 頸の回旋時におこるめまい や眼振は本症で高頻度にみられ, 蝸牛症状を欠いでい る.乙れは脳底動脈さらに前脊檤動脈にも循環障害を 及ぼすもので, 長島 ${ }^{8)}$ は乙れを重視している. われわ れの第 2 ・4 例にはこれらの障害が重要因子であった と考えられる. (3)繰返しの小外傷による铕膜の癒着・肥 厚や小血管壁の肥厚閉塞による神経組織の栄養障害.

また，レ線計測診断についてもかなり2/9) 13) の文献 があるが，本報告の目的ではないので省略する．

手術方法：本症状が機械的因子による圧迫と循環障 害によるものである以上, 術前に少なくとも $2 \sim 4$ 週 間 Skull traction を行ない, 矯正し得る骨の alignment を整えておくととは重要である. Dastur ${ }^{14)} の$ 術直後死亡 5 例は, 率引せず除圧術をした例であった という. 手術方法としては，(1) Laminectomy や大 孔拡大による除圧術, (2)骨移植による fusion, (3) Wiring による固定 ${ }^{15) 16)}$, (4) Acrylic fusion などが 挙げられる.これらを個々に行うか, 幾つかを組合せ る方法がとられている. われわれの教室では以前， Staplingによる後頭骨一移植骨片の固定で posterior 
fusion がうまく行なわれた 2 例がある. との場合， 長期間の外固定が必要である.

骨移植と Wiring による固定法はすでに Mixter ${ }^{15)}$, Alexander ${ }^{17)}$ ，Gulati ${ }^{18)}$ らにより報告され，広く用 いられでるる819)．乙れは骨瘾合が完了するまでの wire による補強力゙離床を早める利点となる. 今回の 症例 1 では, wire を $C_{1}$ Lamina 下に通しで後方へ 引き上げるようにしたが，骨のもろさを考虑して細目 の wire を用いたため断裂をきたし，大孔部付近の 移植骨吸収を招いた失敗を反省している，症例 2 はて の点に留意したので固定は強固である.

Acrylic fusion は比較的近年になって用いられて いるようであるが, Kelly ${ }^{20)}$ は環軸椎変位 5 例に骨七 メントと Wiring による固定を行い, 9 年間 Followup して良好な成績を得ている. 長島8)も N. Dott 法 の良き固定性を強調している. 症例 $3 \cdot 4$ 亿行った （wiring十片側骨移植十反対側骨セメント）の方法 は, 著者が留学中 Brattström ${ }^{21) 22)}$ から習ったもの で，固定法としてはすぐれていると考える，注意す べきは，骨セメントに対する一般的配虑として，(1) Anchoring をよくするてと，(2)重合熱による組織損 傷をさける，(3)感染防止，などが挙げられる。乙れら は人工関節手術の場合と同じである.とくに(2)は, 神 経組織や血管に接するての手術において重要であり， 筋弁または生食水に浸したスポンゼルを下敷とし重合 時に冷たい生食水で洗涤するてとも忘れてはならな い, 他方, 成績の良否は手術方法のみでなく, 症状発 現からの期間が大きく左右することは云うまでもな い.

$$
\text { むす び }
$$

Atlanto-axial dislocation $と$ Basilar impression の 4 例に Decompression. 骨移植・wiring.Acrylic fixation などを行ってその方法を主として検討した.

\section{参考文献}

1) Greenberg, A. D.: Brain. 91, 266 (1968).

2）佐野圭司・他：神経研究の進歩. 8, 263 (1964).

3）村上弓夫・他：整形外科， 25,27 (1974).

4）常徳 他: 日整会誌. 38,820 (1964).

5）金子俍・他：臨床神経学. 5, 174 (1965).

6）荒木淑郎・他：臨床神経学. 1，141 (1961).
7）玉木紀彦・他：脳と神経. 22, 1375 (1970).

8）長島親男: 脳と神経. 20,881 (1968).

9）清水健太郎：臨床外科. 5, 311 (1950).

10）名和田宏：脳と神経. 15, 49 (1963).

11) 名和田宏：脳と神経. 15, 467 (1963).

12）工藤達之・他：脳と神経. 15，48 (1963).

13）鈴木宗治・他：臨床放射線. 11, 1071 (1966).

14) Daster, D. K. et al. : Brain. 88, 897 (1965).

15) Marmor, L. : Surgery of Rheumatoid Arthritis Lea \& Febiger, Phiadelphia (1967).

16) McLaurin, R. L. et al. : J. Neurosurg. 36, 773 (1972).

17) Alexander, E. et al. : J. Neurosurg. 31, 580 (1969).

18) Gulati, D. R. et al. : J. Neurosurg. 40, 349 (1974).

19）大河的凱男 - 他：脳と神経. 20, 137 (1968).

20) Kelly, D. L. et al. : J. Neurosurg. 36, 366 (1972)..

21) Brattström, H. et a1.: Ann. rheum. Dis. 32, 578 (1973).

22) Brattström, H. et al.: Orthopaedic Surgery and Traumatology proceeding of the 12th Congress of the International Society of Orthopaedic Surgery and Traumatology. Tel. Aviv. October 9-12, 407 (1972).

買 問鹿児島大学 酒島 崇

1 ) 症例 2 は $\mathrm{C}_{1}$ のみの椎弓切除で後頭骨の切除は なされていないが，除圧は充分と考えますか.

2 ) Basilar impression の症例に，一般には後頭 除圧が行われているが固定術を加えられた理由をお教 え下さい。

回答熊本大学整形 木村 千似

(1) Bone Cement の重合熱による神経組織の障害 を防ぐためには，Dura 上を筋弁または生食水に浸し た Gelform で覆い熱遮断の一助とするとと, 重合時 に抗生剤が入った冷たい生食水で洗涤して熱の分散を はかるとと，などの注意が必要である。

(2) 症例 2 にも大後頭孔拡大による除圧を行なって いる.

(3) 第 2 例に (Decompression+Occipito vertebral fusion) を行ったのは，頸運動に際して四肢の シビレを訴えたためである. 